\title{
PERBEDAAN PENGARUH LATIHAN PLIOMETRIK SINGLE LEG SPEED HOP DAN DOUBLE LEG SPEED HOP TERHADAP KEMAMPUAN LOMPAT JAUH GAYA JONGKOK DI SMA NEGERI 08 BENGKULU UTARA
}

\author{
Pitria Oktaviani,

\section{Tono Sugihartono} \\ Universitas Bengkulu \\ Arwin \\ Universitas Bengkulu
}

Universitas Bengkulu email: oktavianipitria@gmail.com

\begin{abstract}
Abstrak
Penelitian ini bertujuan untuk mengetahui perbedaan latihan pliometrik single leg speed hop dan double leg speed hop tehadap kemampuan lompat jauh gaya jongkok di SMA Negeri 08 Bengkulu Utara. Jenis penelitian yang digunakan dalam penelitian ini adalah quasi eksperimen. Sampel pada penelitian ini adalah siswa di SMA Negeri 08 Bengkulu Utara yang berjumlah 50 siswa. Analisis statistik yang digunakan adalah uji t. hasil analisis uji t perhitungan perbandingan antara hasil akhir kedua kelompok ternyata terdapat perbedaan yang signifikan. Hasil perhitungan menyatakan bahwa thitung sebesar 3,02 lebih besar dari tabel 2,069 dengan taraf $\alpha=0,05$, sehingga dapat disimpulkan bahwa terdapat perbedaan pengaruh latihan pliometrik single leg speed hop dan double leg speed hop terhadap kemampuan lompat jauh gaya jongkok.
\end{abstract}

Kata kunci : pliometrik, single leg speed hop, double leg speed hop, lompat jauh.

\begin{abstract}
This study aims to determine the differences in pliometric training of single leg speed hops and double leg speed hops on the ability of squat style long jump in SMA Negeri 08 Bengkulu Utara. The type of research used in this study was quasi-experimental. The sample in this study was students at SMA Negeri 08 Bengkulu Utara which numbered 50 students. The statistical analysis used is the $t$ test. The results of the $t$ test analysis of the comparison calculation between the final results of the two groups turned out to have a significant difference. The calculation results state that tcount of 3.02 is greater than ttable 2.069 with the level of $\alpha=0.05$, so it can be concluded that there are differences in the influence of the single leg speed hop pliometric exercise and double leg speed hop hops on the ability of squat style long jump.
\end{abstract}

Keywords: plyometrics, single leg speed hop, double leg speed hop, long jump. 


\section{PENDAHULUAN}

Olahraga merupakan bagian dari kehidupan manusia. Olahraga adalah bagian yang integral dari pendidikan keseluruhan peserta didik, yang berarti kegiatan olahraga yang dirancang dan dilaksanakan di lembaga pendidikan harus berimplikasikan pendidikan. Olahraga dapat digunakan untuk mengajarkan mengembangkan kepribadian dan perilaku yang baik, menguasai keterampilan, memelihara dan meningkatkan kesegaran jasmani. Oleh karena itu, olahraga sudah dikenal dikalangan masyarakat banyak, sehingga anak-anak harus diajarkan untuk berolahraga dimulai dari usia dini.

Salah satu bagian dari pendidikan di lembaga formal adalah pendidikan jasmani, yang secara khusus merupakan pendekatan ke salah satu cabang olahraga tertentu berdasarkan kurikulum yang berlaku. Diantaranya adalah pembelajaran mengenai cabang olahraga atletik. Menurut Mark Guthrie (2000:67) Cabang olahraga altetik mencakup berbagai macam cabang seperti: lari, lompat, dan lempar. Nomor lompat yang diajarkan salah satunya adalah lompat jauh. Lompat jauh adalah hasil dari kecepatan horizontal yang dibuat dari ancang-ancang dengan gerak vertical yang dihasilkan dari kaki tumpu, formulasi dari kedua aspek tadi menghasilkan suatu gaya gerak parabola dari titik pusat gravitasi Djumidar (2005 : 12.40). Lompat jauh yang diajarkan merupakan latihan bagi siswa untuk melakukan gerakan melompat dan mencapai jarak lompatan sejauhjauhnya yang dimulai dengan gerakan lari sebagai awalan dalam melompat kemudian menolak pada papan tumpuan kemudian gerakan melayang di udara dan akhirnya mendarat pada titik terjauh ke dalam bak pasir sebagai media pendaratannya.

Dalam upaya mencapai jarak lompatan yang sejauh-jauh nya, seorang siswa harus memiliki beberapa persyaratan tertentu seperti kondisi fisik, kemampuan, dan penguasaan teknik lompat jauh. Lompat jauh sangat diperlukan kecepatan dan kekuatan otot tungkai untuk mencapai jarak lompatan yang sejauh-jauhnya. Untuk mendapatkan kekuatan otot tungkai yang baik diperlukan latihan fisik. Dengan adanya sebuah latihan, maka apa yang diinginkan dapat tercapai bila dilaksanakan dengan baik. Latihan merupakan suatu proses yang sistematis dalam mempersiapkan atlet pada tingkat tertinggi penampilannya yang dilakukan secara berulang-ulang dengan beban yang semakin tinggi/meningkat (lyakrus, 2012:2).

Dari observasi dan wawancara guru pendidikan jasmani di SMA Negeri 08 Bengkulu Utara terlihat banyak siswa yang masih kurang mampu melakukan lompat jauh gaya jongkok, kurangnya latihan yang menunjang kemampuan lompat jauh, belum ada program latihan untuk lompat jauh khususnya gaya jongkok, latihan rutin hanya dilakukan saat akan ada perlombaan, dan 
pencapaiam prestasi yang kurang khususnya dalam olahraga lompat jauh.

Latihan yang digunakan dalam penelitian ini adalah latihan pliometrik single leg speed hop dan double leg speed hop. James C. Radciffe \& Robert C. Farentinos (2002:1) pliometrik adalah suatu metode untuk mengembangankan daya ledak (eksplosive power), suatu komponen penting dari sebagian besar prestasi atau kinerja. latihan single leg speed hop adalah gerakan meloncat dengan satu tungkai untuk mencapai ketingiian maksimum dan kecepatan maksimum gerakan kaki, latihan ini memberikan peningkatan yang bermakna terhadap kelincahan Urang Windu (2017:6). Latihan double leg Speed Hop merupakan pelatihan untuk mengembangkan Otot-otot tungkai dan pinggul khususnya kerja otot-otot gluteals, hamstring, quartriceps dan gastrocenemius dengan kecepatan yang tinggi dan penuh tenaga (Maulidin, 2016:490).

Oleh sebab itu, peneliti merasa tertarik melakukan penilitian eksperimen di SMA Negeri 08 Bengkulu Utara dengan judul "Perbedaan Pengaruh Latihan Pliometrik single leg speed hop dan double leg speed hop terhadap Kemampuan Lompat Jauh Gaya Jongkok di SMA Negeri 08 Bengkulu Utara".

\section{METODE}

Jenis penelitian yang digunakan dalam penelitian ini adalah quasi eksperimen. Menurut Sugiyono (2016:72) Penelitian eskperimen dapat diartikan sebagai metode penelitian yang digunakan untuk mencari pengaruh perlakuan tertentu terhadap yang lain dalam kondisi yang terkendali. Dalam penelitian ini terdapat dua variabel yang akan dikaitkan, yaitu variabel bebas dan variabel terikat. Adapun variabel bebas dalam penelitian ini adalah latihan pliometrik single leg speed hop dan double leg speed hop, sedangkan variabel terikatnya adalah kemampuan lompat jauh gaya jongkok.

Populasi dalam penelitian ini adalah seluruh siswa di SMA Negeri 08 Bengkulu Utara, sedangkan sampel yang digunakan adalah 50 siswa perempuan di SMA Negeri 08 Bengkulu Utara. Teknik pengumpulan data dalam penelitian ini adalah tes dan pengukuran. Widiastuti (2011 : 2) Tes adalah alat yang digunakan untuk mengukur beberapa performa dan untuk mengumpulkan data. Tes yang dimaksud adalah tes awal dan tes akhir lompat jauh gaya jongkok. Instrumen penelitian adalah alat pengumpul data dalam suatu penelitian (Dian Pujianto \& Bayu Insanistyo, 2013:61). Instrumen yang digunakan dalam penelitian ini adalah tes kemampuan lompat jauh gaya jongkok. Penelitian ini menggunakan perhitungan statistik uji t.

\section{HASIL DAN PEMBAHASAN}

HASIL

Hasil tes awal lompat jauh gaya jongkok kelompok 1 didapat nilai minimum 226, nilai maksimum 330, mean (rata-rata) 267, dan simpangan baku 20,99. Sedangkan kelompok 2 
didapat nilai minimum 227, nilai maksimum 334, mean (rata-rata) 266,8 dan simpangan baku 22,45.

Tabel 1

Deskripsi statistik tes awal kedua kelompok

\begin{tabular}{|c|c|c|c|}
\hline $\begin{array}{c}\mathrm{N} \\
\mathrm{O}\end{array}$ & $\begin{array}{c}\text { Deskripsi } \\
\text { statistik }\end{array}$ & $\begin{array}{c}\text { Kelompok } \\
1\end{array}$ & $\begin{array}{c}\text { Kelompok } \\
2\end{array}$ \\
\hline 1 & $\begin{array}{c}\text { Nilai } \\
\text { minimum }\end{array}$ & 226 & 227 \\
\hline 2 & $\begin{array}{c}\text { Nilai } \\
\text { maksimum }\end{array}$ & 330 & 334 \\
\hline 3 & $\begin{array}{c}\text { Mean (rata- } \\
\text { rata) }\end{array}$ & 267 & 266,8 \\
\hline 4 & $\begin{array}{c}\text { Simpangan } \\
\text { baku }\end{array}$ & 20,99 & 22,45 \\
\hline 5 & Varian & 440,58 & 504 \\
\hline
\end{tabular}

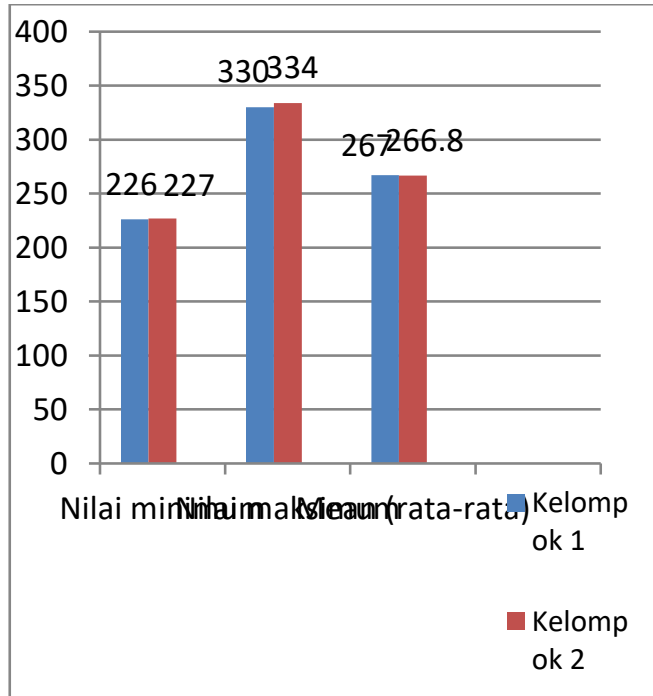

\section{Gambar 1}

\section{Diagram tes awal kedua kelompok}

Hasil tes akhir lompat jauh gaya jongkok kelompok 1 didapat nilai minimum 238, nilai maksimum 345, mean (rata-rata) 279,9, dan simpangan baku 22,4. Sedangkan kelompok 2 didapat nilai minimum 247, nilai maksimum 360, mean (rata-rata) 298 dan simpangan baku 22,93.
Tabel 2

Deskripsi statistik tes akhir kemampuan lompat jauh

\begin{tabular}{|c|c|c|c|}
\hline $\begin{array}{l}\mathrm{N} \\
\mathrm{O}\end{array}$ & $\begin{array}{l}\text { Deskripsi } \\
\text { statistik }\end{array}$ & $\begin{array}{c}\text { Kelompok } \\
1\end{array}$ & $\begin{array}{c}\text { Kelompok } \\
2\end{array}$ \\
\hline 1 & $\begin{array}{c}\text { Nilai } \\
\text { minimum }\end{array}$ & 238 & 247 \\
\hline 2 & $\begin{array}{c}\text { Nilai } \\
\text { maksimum }\end{array}$ & 345 & 360 \\
\hline 3 & $\begin{array}{c}\text { Mean (rata- } \\
\text { rata) }\end{array}$ & 279,9 & 298 \\
\hline 4 & $\begin{array}{c}\text { Simpangan } \\
\text { baku }\end{array}$ & 22,4 & 22,93 \\
\hline 5 & Varian & 501,76 & 525,78 \\
\hline
\end{tabular}

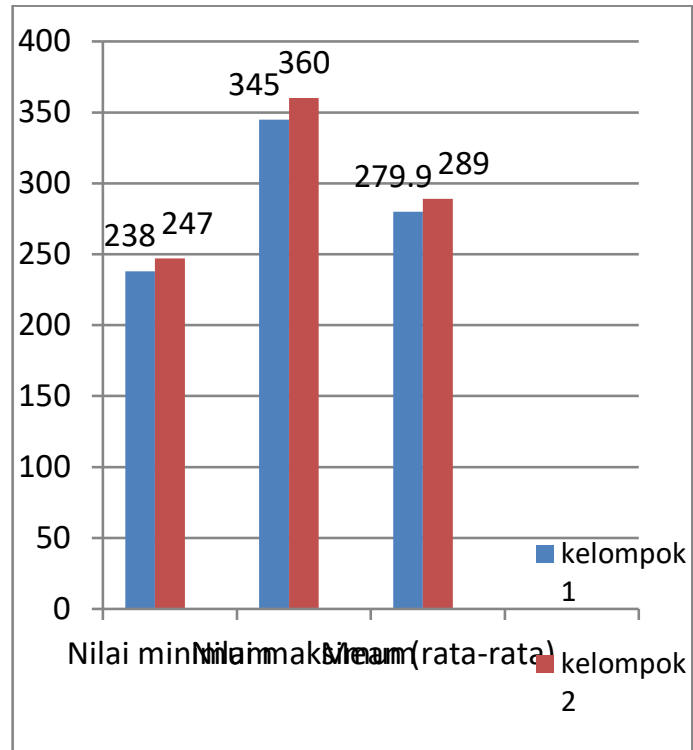

\section{Gambar 2}

\section{Grafik tes akhir kedua kelompok}

Hasil dari pengujian normalitas pada data tes awal dengan $\mathrm{n}=25$ pada taraf signifikan $\alpha=0,05$ diperoleh $X^{2}$ tabel $=11,070$ yang lebih besar dari $X^{2}$ hitung sehingga dapat disimpulkan skor yang diperoleh dari data tes awal kemampuan lompat jauh gaya jongkok berdistribusi normal. 
Tabel 3

\section{Hasil uji normalitas tes awal}

\begin{tabular}{|l|l|l|l|l|}
\hline $\begin{array}{l}\mathrm{N} \\
\mathrm{O}\end{array}$ & $\begin{array}{l}\text { Kemampuan } \\
\text { lompat jauh } \\
\text { gaya } \\
\text { jongkok }\end{array}$ & $\begin{array}{l}\mathrm{X}^{2} \\
\text { hitung }\end{array}$ & $\begin{array}{l}\mathrm{X}^{2} \\
\text { tabel }\end{array}$ & Ket \\
\hline 1 & Kelompok 1 & 9,5 & $\begin{array}{l}11,07 \\
0\end{array}$ & $\begin{array}{l}\text { Norm } \\
\text { al }\end{array}$ \\
\hline 2 & Kelompok 2 & 7,23 & $\begin{array}{l}11,07 \\
0\end{array}$ & $\begin{array}{l}\text { Norm } \\
\text { al }\end{array}$ \\
\hline
\end{tabular}

Hasil dari pengujian normalitas pada data tes awal dengan $n=25$ pada taraf signifikan $\alpha=0,05$ diperoleh $X^{2}$ tabel $=11,070$ yang lebih besar dari $X^{2}$ hitung sehingga dapat disimpulkan skor yang diperoleh dari data tes akhir kemampuan lompat jauh gaya jongkok berdistribusi normal.

\section{Tabel 4}

Hasil uji normalitas tes akhir

\begin{tabular}{|l|l|l|l|l|}
\hline $\begin{array}{l}\mathrm{N} \\
\mathrm{O}\end{array}$ & $\begin{array}{l}\text { Kemampuan } \\
\text { lompat jauh } \\
\text { gaya } \\
\text { jongkok }\end{array}$ & $\begin{array}{l}\mathrm{X}^{2} \\
\text { hitung }\end{array}$ & $\begin{array}{l}\mathrm{X}^{2} \\
\text { tabel }\end{array}$ & Ket \\
\hline 1 & Kelompok 1 & 9,77 & $\begin{array}{l}11,07 \\
0\end{array}$ & $\begin{array}{l}\text { Norm } \\
\text { al }\end{array}$ \\
\hline 2 & Kelompok 2 & 5,99 & $\begin{array}{l}11,07 \\
0\end{array}$ & $\begin{array}{l}\text { Norm } \\
\text { al }\end{array}$ \\
\hline
\end{tabular}

Dalam uji homogenitas Uji $\mathrm{F}$ di dapat $F$ hitung tes awal adalah 1,13 dan tes akhir 1,00, sedangkan $\mathrm{F}$ tabel dengan $d k=\left(n_{1}-1, n_{2}-1\right)=(25-1,25-1)=(24,24)$ didapat $F$ tabel adalah 1,98 . $F$ hitung $\leq F$ tabel sehingga dapat disimpulkan bahwa varian-varian homogen.

\section{Tabel 5}

\section{Hasil uji homogenitas tes awal dan tes} akhir

\begin{tabular}{|l|l|l|l|l|}
\hline $\begin{array}{l}\mathrm{N} \\
\mathrm{o}\end{array}$ & $\begin{array}{l}\text { Kelomp } \\
\text { ok }\end{array}$ & $\begin{array}{l}\mathrm{F} \\
\text { hitung }\end{array}$ & $\begin{array}{l}\mathrm{F} \\
\text { tabel }\end{array}$ & Ket \\
\hline 1 & $\begin{array}{l}\text { Tes } \\
\text { awal }\end{array}$ & 1,13 & 1,98 & Homogen \\
\hline
\end{tabular}

\begin{tabular}{|l|l|l|l|l|}
\hline 2 & $\begin{array}{l}\text { Tes } \\
\text { akhir }\end{array}$ & 1,00 & 1,98 & Homogen \\
\hline
\end{tabular}

Diketahui bahwa uji t antar pretest kedua kelompok tidak ada perbedaan. Hal ini dapat dilihat dari hasil perhitungan thitung $0,03<t_{\text {tabel }}$ 2,069, maka Ho diterima. Tidak adanya perbedaan pengaruh latihan pliometrik single leg speed hop dan double leg speed hop terhadap kemampuan lompat jauh gaya jongkok di SMA Negeri 08 Bengkulu Utara.

Hasil pre-test dan post-test pada latihan single leg speed hop terdapat perbedaan yang signifikan, hal ini diketahui thitung $=2,11$ dan $t_{\text {tabel }}$ dengan derajat kebebasan $(\mathrm{dk})=\mathrm{n}-2=25-2=$ 23 didapat $t_{\text {tabel }}=2,069$. Sehingga $t_{\text {hitung }}$ $=2,11>t_{\text {tabel }}=2,069$, artinya latihan pliometrik single leg speed hop berpengaruh pada kemampuan lompat jauh gaya jongkok di SMA Negeri 08 Bengkulu Utara.

Terdapat perbedaan pada hasil pre-test dan post-test latihan double leg speed hop, hal ini dapat diketahui dari harga $t_{\text {tabel }}$ dengan derajat kebebasan $(\mathrm{dk})=\mathrm{n}-2=25-2=23$ dari daftar distribusi $t_{\text {tabel }}$ adalah 2,069. Sedangkan $t_{\text {hitung }}=5,09$, maka $t_{\text {hitung }}>t_{\text {tabel. }}$. Artinya latihan double leg speed hop berpengaruh pada kemampuan lompat jauh gaya jongkok di SMA Negeri 08 Bengkulu Utara.

Hasil uji t antar post-test kedua kelompok terdapat perbedaan, dapat dilihat dari thitung 3,02 > tabel 2,069, maka $\mathrm{Ha}$ diterima. Adanya perbedaan pengaruh latihan pliometrik single leg speed hop dan double leg speed hop 
terhadap kemampuan lompat jauh gaya jongkok di SMA Negeri 08 Bengkulu Utara.

\section{Tabel 6}

\section{Hasil pengujian hipotesis}

\begin{tabular}{|c|c|c|c|}
\hline Data & $t_{\text {hitung }}$ & $t_{\text {tabel }}$ & Ket \\
\hline $\begin{array}{l}\text { Antar Pre- } \\
\text { test }\end{array}$ & 0,03 & 2,069 & $\begin{array}{l}\text { Tidak } \\
\text { adanya } \\
\text { perbedaa } \\
\mathrm{n}\end{array}$ \\
\hline $\begin{array}{l}\text { Pre-test dan } \\
\text { post-test } \\
\text { latihan } \\
\text { single leg } \\
\text { speed hop }\end{array}$ & 2,11 & 2,069 & $\begin{array}{l}\text { Adanya } \\
\text { perbedaa } \\
n\end{array}$ \\
\hline $\begin{array}{l}\text { Pre-test dan } \\
\text { post-test } \\
\text { latihan } \\
\text { double leg } \\
\text { speed hop }\end{array}$ & 5,09 & 2,069 & $\begin{array}{l}\text { Adanya } \\
\text { perbedaa } \\
n\end{array}$ \\
\hline $\begin{array}{l}\text { Antar post- } \\
\text { test }\end{array}$ & 3,02 & 2,069 & $\begin{array}{l}\text { Adanya } \\
\text { perbedaa } \\
\mathrm{n}\end{array}$ \\
\hline
\end{tabular}

Dari tabel 14 dapat diketahui bahwa kelompok 1 memiliki presentase peningkatan sebesar $4 \%$ dan kelompok 2 memiliki presentase peningkatan sebesar 11\%. Sehingga dapat disimpulkan bahwa kelompok 2 yang menggunakan latihan double leg speed hop memiliki presentase kemampuan lompat jauh gaya jongkok yang lebih besar dari kelompok 1 yang menggunakan latihan single leg speed hop.

\section{Tabel 7}

Presentase peningkatan kemmapuan lompat jauh gaya jongkok

\begin{tabular}{|c|l|l|l|l|l|}
\hline Sampel & N & $\begin{array}{l}\text { Mean } \\
\text { pre- } \\
\text { test }\end{array}$ & $\begin{array}{l}\text { Mean } \\
\text { post- } \\
\text { test }\end{array}$ & $\begin{array}{l}\text { Mean } \\
\text { differe } \\
\text { nt }\end{array}$ & $\begin{array}{l}\text { Prese } \\
\text { ntase }\end{array}$ \\
\hline $\begin{array}{c}\text { Kelompo } \\
\text { k 1 }\end{array}$ & 25 & 267 & 278,9 & 11,9 & $4 \%$ \\
\hline
\end{tabular}

\begin{tabular}{|c|c|c|c|c|c|}
\hline $\begin{array}{c}\text { Kelomp } \\
\text { ok 2 }\end{array}$ & 25 & 266,8 & 298,6 & 31,8 & $11 \%$ \\
\hline
\end{tabular}

\section{PEMBAHASAN}

Data awal diambil dari hasil lompat jauh gaya jongkok siswa, kemudian dibagi menjadi dua kelompok. Kelompok 1 memiliki nilai minimum 226, nilai maksimum 330, dan mean (rata-rata) 267. Kelompok 2 memiliki nilai minimum 227, nilai maksimum 334, dan mean (rata-rata) 266,8. Kedua kelompok diberi perlakuan selama 16 kali pertemuan. Kelompok 1 diberi perlakuan latihan single leg speed hop dan kelompok 2 diberi perlakuan latihan double leg speed hop dengan waktu yang sama. Kemudian setelah 16 kali pertemuan diberi perlakuan, siswa melakukan tes akhir lompat jauh gaya jongkok.

Data hasil tes awal dan tes akhir dihitung menggunakan uji normalitas dan uji homogenitas. Setelah mendapatkan hasil yang normal dan homogen, data kemudian di hitung menggunakan uji t.

Kelompok 1 memiliki presentase peningkatan sebesar $4 \%$ sedangkan kelompok 2 memilik presentase peningkatan sebesar $11 \%$. Hasil presentase peningkatan kedua kelompok membuktikan bahwa kelompok 2 yang diberi perlakuan latihan double leg speed hop lebih baik dari kelompok 1 yang diberi perlakuan latihan single leg speed hop.

Dengan dilakukan latihan pliometrik single leg speed hop dan double leg speed hop selama 16x latihan 
mampu meningkatkan kekuatan otot tungkai sehingga kemampuan lompat jauhnya juga meningkat. Seperti yang dijelaskan oleh James C. Radciffe \& Robert C. Farentinos (2002:69-72) Gerakan pliometrik diyakini berdasarkan kontraksi refleks serabut-serabut otot sebagai akibat pembebanan yang cepat. Reseptor sensori utama yang bertanggung jawab atas deteksi pemanjangan serabut-serabut otot yang cepat ini adalah muscle spindle, yang mampu memberi respon kepada besaran dan kecepatan perubahan panjang serabut-serabut otot.. Jika kadar peregangannya bertambah maka kecepatan pemancaran impuls-impuls syaraf juga meningkat.

Pada saat melakukan lompatan, ketika kaki menyentuk lantai atau tanah, tungkai mulai menekuk karena adanya beban gaya-gaya yang lebih besar seperti yang dikemukakan oleh James $C$. Radciffe \& Robert C. Farentinos (2002:75) Besar kecilnya pembengkokan tungkai karena adanya gaya tersebut sebagian besar ditentukan oleh tingkat aktivitas refleks muscle spindle. Jika efferen-efferen gamma yang bertanggung jawab atas pengontrolan tingkat statis dari muscle spindle sangat aktif, sehingga refleks dinamis berada pada tingkat yang lebih tinggi, maka pemanjangan yang sedikit saja pada quadriceps (dan karenanya juga muscle spindle quadriceps) akan menyebabkan kontraksi yang sangat kuat pada otototot ini karena adanya refleks dinamis.

Siswa yang menggunakan latihan pliometrik double leg speed hop lebih mampu menyeimbangkan badan, mengatur napas, dan dapat meningkatkan kekuatan/power otot mereka. Sehingga apabila kekuatan otot baik maka kemampuan lompat jauh nya juga akan baik. Sesuai dengan pendapat James C. Radciffe \& Robert C. Farentinos (2002:1) pliometrik adalah suatu metode untuk mengembangankan daya ledak (eksplosive power), suatu komponen penting dari sebagian besar prestasi atau kinerja. Setiap keterampilan olahraga yang menuntut power, yaitu kombinasi atau perpaduan antara kekuatan dan kecepatan, dapat diperoleh manfaat dari latihan pliometrik.

\section{PENUTUP}

\section{SIMPULAN DAN SARAN}

Berdasarkan hasil penelitian dan pembahasan yang telah diuraikan pada bab sebelumnya dapat disimpulkan bahwa hipotesis yang diajukan diterima, yaitu adanya perbedaan pengaruh latihan pliometrik single leg speed hop dan double leg speed hop terhadap kemampuan lompat jauh gaya jongkok di SMA Negeri 08 Bengkulu Utara. Dengan perhitungan statistik uji $t$ dimana $t_{\text {hitung }} 3,02>t_{\text {tabel }} 2,069$ pada $\alpha=0,05$ dan dapat disimpulkan bahwa adanya perbedaan yang signifikan antara latihan pliometrik single leg speed hop dan double leg speed hop terhadap kemampuan lompat jauh gaya jongkok. Latihan pliometrik double leg speed hop lebih baik dari pada latihan pliometrik single leg speed hop dalam 
meningkatkan kemampuan lompat jauh gaya jongkok.

Berdasarkan kesimpulan diatas, maka peneliti memberikan saran yang mampu membantu mengatasi masalah yang ditemukan dalam pencapaian lompat jauh gaya jongkok dalam olahraga atletik yaitu: (1)Berdasarkan hasil penelitian, seorang guru olahraga khususnya pada lompat jauh untuk dapat menerapkan latihan pliometrik double leg speed hop guna meningkatkan kemampuan lompat jauh. (2) Untuk mendapatkan hasil yang maksimal untuk lompat jauh seharusnya ada latihan rutin khususnya latihan double leg speed hop. (3)Untuk siswa sebaiknya menggunakan latihan double leg speed hop untuk meningkatkan kemampuan lompat jauh gaya jongkok.

\section{DAFTAR PUSTAKA}

Djumidar. 2005. Dasar-Dasar Atletik. Jakarta: Universitas Terbuka.

Guthrie, Mark. 2008. Sukses Melatih Atletik. Yokyakarta: PT Pustaka Insan Madani.

Iyakrus. 2012. Penerapan Closed Skill dan Open Skill dalam Latihan Sepaktakraw di Penjas FKIP Universitas Sriwijaya, Jurnal Ilmu Olahraga \& Kesehatan, Vol.2 (1) hal. 2.

Maulidin. 2016. Metode Latihan Double Leg Bound dan Double Leg Speed Hop Untuk Meningkatkan Power Otot Tungkai Atlit Renang Mataram, Journal Education, Vol 3 (2) hal. 489.
Pujianto, Dian \& Insanistyo, Bayu. 2013. Dasar-Dasar Penelitian Pendidikan Jasmani. Bengkulu: Universitas Bengkulu

Radcliffe, C. J dan Farentinos C. R. 2002. Plaiometrik Untuk Meningkatkan Power. Srakarta: Program Pascasarjana Universitas Sebelas Maret.

Sugiyono. 2016. Metode Penelitian Kuantitatif, Kualitatif, dan $R \& D$. Bandung: Alfabeta, cv.

Widiastuti. 2011. Tes dan Pengukuran Olahraga. Jakarta: PT Bumi Timur Jaya.

Windu, Urang. 2017. Perbedaan Pengarh Latihan Single Leg Speed Hop dengan Latihan Knee Tuck Jump Terhadap Peningkatan Kelincahan pada Pemain Futsal [skripsi]. Yogyakarta: Universitas 'Aisyiyah Yogyakarta. 